J. Natn. Sci. Coun. Sri Lanka $199220(2): 191-199$

\title{
TOXICITY OF HYDROGEN SULPHIDE TO JUVENILES OF MACROBRACHIUM ROSENBERGII
}

\author{
S.C. JAYAMANNE \\ National Aquatic Resources Agency, Crow Island, Mattakkuliya, Colombo 15.
}

(Date of receipt : $\quad$ 13 November 1990)

(Date of acceptance : 11 February 1992)

\begin{abstract}
Static bio-assays were performed for $96 \mathrm{~h}$ to determine the mean lethal concentrations $\left(\mathrm{LC}_{50}\right)$ of hydrogen sulphide for juveniles of Macrobrachium rosenbergii De Man. Broods of two size classes were tested and $\mathrm{LC}_{50}$ values were determined for $24,48,72$ and $96 \mathrm{~h}$. The $\mathrm{LC}_{50}$ values were $6.36,4.25,3.09$ and 2.57 $\mathrm{mg} / 1 \mathrm{H}_{2} \mathrm{~S}$ for brood $1(7.26 \pm 0.85 \mathrm{~mm})$ and $5.57,4.79,4.25$ and 4.20 for brood 2 ( 15.08 $\pm 1.08 \mathrm{~mm}$ ) respectively, for $24,48,72$ and $96 \mathrm{~h}$. The safe concentration of hydrogen sulphide for juveniles of $M$. rosenbergii was determined to be $0.26 \mathrm{mg} / 1$.
\end{abstract}

\section{INTRODUCTION}

Hydrogen sulphide is a toxic gas which is harmful to aquatic life, particularly in the un-ionized form. It may occur naturally in water, at levels which can be inimical to fish production and survival. 1 . Under natural conditions it is produced by the anaerobic decomposition of organic materials in sediments. It can also be produced either by the decomposition of organic effluents from municipal sewage and many industries ${ }^{1}$ or released directly in industrial effluents from pulp mills ${ }^{2}$, from oil refineries ${ }^{3}$, and from chemical and gas industries. ${ }^{4}$ In fish culture ponds, it is liberated as a result of decomposition of food and organic matter. ${ }^{5}$

The toxic effects of hydrogen sulphide to fish have been reviewed by Adelman and Smith. ${ }^{6}$ Smith and Oseid ${ }^{7}$ reported reduced swimming endurance of bluegill sunfish (Lepomis macrochirus) after exposure to $0.04 \mathrm{mg} / \mathrm{l} \mathrm{H}_{2} \mathrm{~S}$. Even very low concentrations of $\mathrm{H}_{2} \mathrm{~S}$ have been shown to be detrimental to fish eggs, fry and juveniles. ${ }^{1,6,7}$ Long term exposure of fish to sub-lethal levels can slow growth, increase mortality and reduce fecundity. Sub-lethal levels of $\mathrm{H}_{2} \mathrm{~S}$ also can influence the hatching of fry ${ }^{1}$ and cause anatomical malformations. ${ }^{6}$ Fish mortality due to $\mathrm{H}_{2} \mathrm{~S}$ was reported by Colman

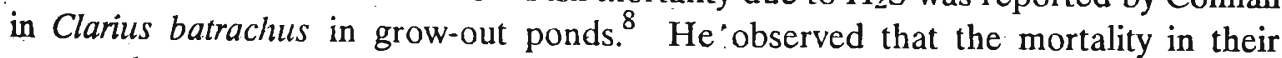
system depended primarily upon the presence or absence of $\mathrm{H}_{2} \mathrm{~S}$. Peturiyawate ${ }^{9}$ determined the median lethal concentrations ( $\mathrm{LC}_{50}$ ) for the fingerlings of Clarius batrachus. ${ }^{9}$ The author estimated $6.32 \mathrm{mg} / \mathrm{l}$ and $5.31 \mathrm{mg} / \mathrm{l}$ of $\mathrm{H}_{2} \mathrm{~S}$ as the $\mathrm{LC}_{50}$ levels for $24 \mathrm{~h}$ and $48 \mathrm{~h}$, respectively.

However, there are very few studies carried out on the effect of $\mathrm{H}_{2} \mathrm{~S}$ on crustaceans. Smith ${ }^{11}$ studied the effects of $\mathrm{H}_{2} \mathrm{~S}$ on a crustacean Gammarus 
pseudolimnaeus used as fish food, and indicated safe levels between 0.002 and 0.003 $\mathrm{mg} / \mathrm{l}^{11}$

In the present study, experiments were performed to determine the $\mathrm{LC}_{50}$ values for juveniles of the giant freshwater prawn Macrobrachium rosenbergii De Man. This species was selected for two main reasons, viz. 1) its importance as an economically valuable and popularly cultured species in the Indo-Pacific region; 2) unsolved sudden mortalities occurring in grow-out ponds during the latter part of culture.

\section{METHODS AND MATERIALS}

Static bio-assays were performed for $96 \mathrm{~h}$ on two separate broods of 21-day and 2 month-old juveniles. Body weights of the specimens from the two broods were measured using a Sartorius balance with a precision of four decimal points. The body lengths of the specimens from the two broods were measured under the microscope using a stage micrometer. The mean \pm S.E. body weights of the specimens of the $1^{\text {st }}$ and $2^{\text {nd }}$ broods were $0.0028 \pm 0.006 \mathrm{~g}$ and $0.005 \pm 0.002 \mathrm{~g}$ while the mean body lengths were $7.25 \pm 0.85 \mathrm{~mm}$ and $15.08 \pm 1.08 \mathrm{~mm}$ respectively.

Test solutions were prepared by diluting $\mathrm{Na}_{2} \mathrm{~S} .9 \mathrm{H}_{2} \mathrm{O}$ fresh stock solution (1000 $\mathrm{mg} / \mathrm{l}$ ), prepared using deoxygenated distilled water. Dilution water was analysed for dissolved oxygen, $\mathrm{pH}$, total alkalinity, total hardness, temperature and dissolved sulphides, prior to the experiment and once daily after the experiment was started. Temperature was measured using a thermometer, $\mathrm{pH}$ by a $\mathrm{pH}$ meter (ORION Ltd.). Dissolved oxygen was measured using a DO meter (YSI Model). Total alkalinity, total hardness and total sulphide were measured titrimetrically. ${ }^{10}$

A preliminary test was conducted to find out the critical range prior to the full-scale experiment. For the full-scale experiment concentrations of $1 \mathrm{mg} / \mathrm{l}, 2 \mathrm{mg} / \mathrm{l}$, $4 \mathrm{mg} /, 6 \mathrm{mg} / \mathrm{l}$ and $8.0 \mathrm{mgl}$ were tested along with a control. All test solutions were renewed every $24 \mathrm{~h}$, at which time the $\mathrm{H}_{2} \mathrm{~S}$ concentration was never less than $88 \%$ of the specified levels.

Tests were performed in 2 litre flasks covered with cork lids. Ten juveniles were placed in each flask and each concentration was run in triplicate for a total of 30 animals per concentration. Each experiment was repeated twice. The juveniles were starved for $24 \mathrm{~h}$ prior to the commencement of experiment and were not fed during the experimental period.

Dead prawns were counted and recorded at the exposure times of $1,2,3,6,9,12,24,48,72$ and $96 \mathrm{~h}$ respectively. The death was defined as opaqueness in immobile animals and the dead prawns were removed from the test solutions immediately. 
The $\mathrm{LC}_{50}$ values and $95 \%$ confidence intervals were calculated as described by Finney. ${ }^{12}$ The data were analysed statistically by two-way ANOVA, the dependant variable being the time of death for each juvenile. Mortality of the controls, was $0 \%$ at the end of $96 \mathrm{~h}$ period. The LC 50 value and $95 \%$ confidence limits of $96 \mathrm{~h}$ period for brood 2 were calculated according to the Litchfield and Wilcoxon. ${ }^{13}$

\section{RESULTS AND DISCUSSION}

The chemical characteristics of dilution water are shown in Table 1. The dilution water used for brood 2 indicated higher $\mathrm{pH}$ and $\mathrm{DO}$ although the water was obtained from the same tank. Differences in temperature in water used in experiments involving brood 1 and 2 is specially due to the climatic changes. First brood was tested in late December, 1985, when the ambient temperature was low, while brood 2 was tested during early February, 1986, when the ambient temperature was higher.

Table 1. Chemical characteristics of the dilution water used in bioassay experiments.

\begin{tabular}{lcc}
\hline Parameter & $\begin{array}{l}\text { Dilution water } \\
\text { used for brood 1 }\end{array}$ & $\begin{array}{l}\text { Dilution water } \\
\text { used for brood 2 }\end{array}$ \\
\hline Dissolved oxygen $(\mathrm{mg} / \mathrm{l})$ & $5.4 \pm 1.21$ & $6.1 \pm 1.32$ \\
$\mathrm{pH}$ & $8.0 \pm 0.20$ & $8.8 \pm 0.15$ \\
Temperature $\left({ }^{\circ} \mathrm{C}\right)$ & $21.6 \pm 4.26$ & $26.1 \pm 0.50$ \\
Alkalinity as $\mathrm{CaCO}_{3}(\mathrm{mg} / \mathrm{l})$ & $224 \pm 4.26$ & $242 \pm 5.68$ \\
Total hardness $(\mathrm{mg} / \mathrm{l})$ & $290 \pm 2.78$ & $301 \pm 3.83$ \\
\hline
\end{tabular}

In all the test solutions prawns exhibited erratic movements. In the highest concentration $(3.0 \mathrm{mg} / \mathrm{l})$, erratic movement began after $30 \mathrm{~min}$ of exposure; while in the lowest concentration $(1.0 \mathrm{mg} / \mathrm{l})$ it began only after $80-96 \mathrm{~h}$. The prawns swam up and down around the flask at the beginning and later jumped to the sides of the flask. They began to lose balance, swim to the surface and come down rapidly in upside down position and in a zig zag manner. They moved weakly at the bottom and died after a period of time. A similar behaviour of Macrobrachium rosenbergii juveniles exposed to lead was documented by Kalayanamitr. ${ }^{14}$ He suggested that the erratic movement may be due to the affected central and peripheral nervous system. The major effect of hydrogen sulphide is exerted on the nervous system, the eyes and the respiratory system and the type of poisoning depends on the duration and level of exposure to gas. ${ }^{15}$ In the present study it was observed that the prawns lost balance in test solutions indicating that their nervous systems were affected.

Percentage mortality of juvenile prawns in relation to exposure times are given in Table 2. A $100 \%$ mortality occurred both in brood 1 and 2 within a $24 \mathrm{~h}$ period at the highest concentration $(8.0 \mathrm{mg} / \mathrm{l})$. At the $6.0 \mathrm{mg} / 1$ concentration $100 \%$ mortality 
occurred at $96 \mathrm{~h}$ period. No mortality was observed in any of the test solutions due to cannibalism although this species is well known for their cannibalistic nature. Some attempts at feeding on dead prawns were observed but this was prevented by removing the dead prawns immediately. The relationship between exposure time and \% mortality observed in the present instance is different from that observed for fish. In a study of Clarius batrachus, Peturiyawate 9 observed that the fish get adapted to the toxic environment after $24 \mathrm{~h}$ of exposure. ${ }^{9}$ In the present study the mortality increased with the time of exposure until the end of the experiment.

Table 2. Percent mortality of the $M$. rosenbergii juveniles exposed to different concentrations of hydrogen sulphide for $24 \mathrm{~h}, 48 \mathrm{~h}, 72 \mathrm{~h}$ and $96 \mathrm{~h}$.

\begin{tabular}{lcccccc}
\hline $\begin{array}{l}\text { Concentration } \\
\text { of } \mathrm{H}_{2} \mathrm{~S}(\mathrm{mg} / \mathrm{l})\end{array}$ & $\begin{array}{l}\text { Number } \\
\text { tested }\end{array}$ & Brood & \multicolumn{4}{c}{ Exposure time (h) } \\
\hline 0 & 30 & 1 & 0 & 0 & 0 & 0 \\
& & 2 & 0 & 0 & 0 & 0 \\
1.0 & 30 & 1 & 0 & 3.3 & 3.3 & 3.3 \\
& & 2 & 0 & 0 & 0 & 0 \\
2.0 & 30 & 1 & 0 & 3.3 & 10.3 & 23.3 \\
& & 2 & 0 & 3.3 & 3.3 & 13.3 \\
4.0 & 30 & 1 & 3.3 & 43.3 & 73.3 & 86.7 \\
& & 2 & 10.3 & 20.7 & 26.7 & 46.7 \\
6.0 & 30 & 1 & 46.7 & 70.0 & 96.7 & 100 \\
& & 2 & 60.0 & 80.0 & 96.7 & 100 \\
8.0 & 30 & 1 & 76.7 & 100 & - & - \\
& & 2 & 93.3 & 100 & - & - \\
\hline
\end{tabular}

Percent mortality of juvenile prawns in relation to concentrations are given in Figure 1 and 2. Percent mortality increased with the increase in concentrations.

The two broods of juveniles were similar in susceptibility to $\mathrm{H}_{2} \mathrm{~S}$ concentration. At exposure times of $24,48,72$, and $96 \mathrm{~h}$, no significant difference was found $(p<0.005)$ in the \% mortalities between the two broods.

The $\mathrm{IC}_{50}$ values, their confidence limits are presented in Table $3 . \mathrm{LC}_{50}$ value for $96 \mathrm{~h}$ were $2.57 \mathrm{mg} / \mathrm{l}$ and $4.2 \mathrm{mg} / 1$ respectively for brood 1 and brood 2 . The differences in $\mathrm{LC}_{50}$ values for specimens of brood 1 and brood 2 may probably be due to either the size of the prawn or the water quality; specially $\mathrm{pH}, \mathrm{DO}$ and temperature. According to the toxicity curve (Figure 3 ) the smaller juveniles seem to get adjusted to the toxic environment easily compared to the bigger ones. However, during the tests conducted with brood 2 specimens, $\mathrm{pH}$ and DO were higher compared to the 
brood 1. Adelman and Smith reported that lower oxygen levels resulted in lower $\mathrm{LC}_{50}$ values in finfish. ${ }^{16}$ Colby and Smith ${ }^{1}$ and Adelman and Smith ${ }^{6}$ found the same effect in other finfish species, although the latter authors found no effect of oxygen differences on the toxicity of hydrogen sulphide to northern pike eggs. In the present study, the specimens from brood 2 which were at a lower dissolved oxygen level

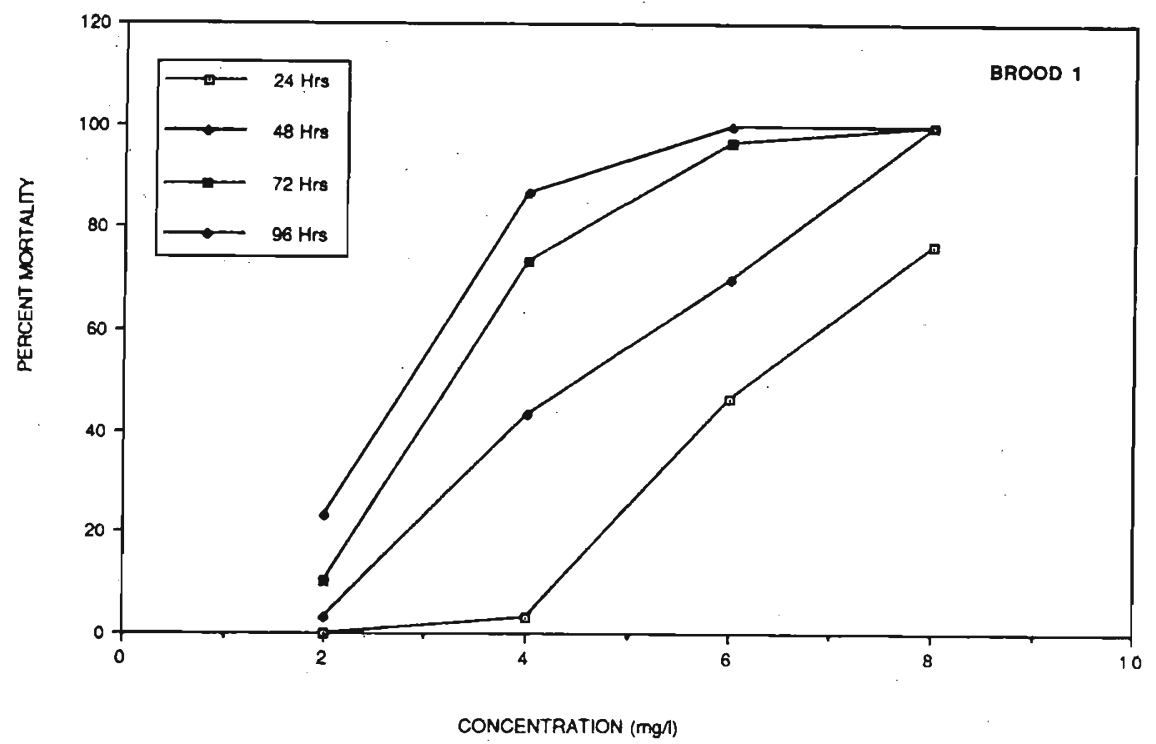

Figure 1: Per cent mortality of the juveniles of $M$. rosenbergit (brood 1) exposed to different concentrations of hydrogen sulphide for $24,48,72$ and $96 \mathrm{~h}$.

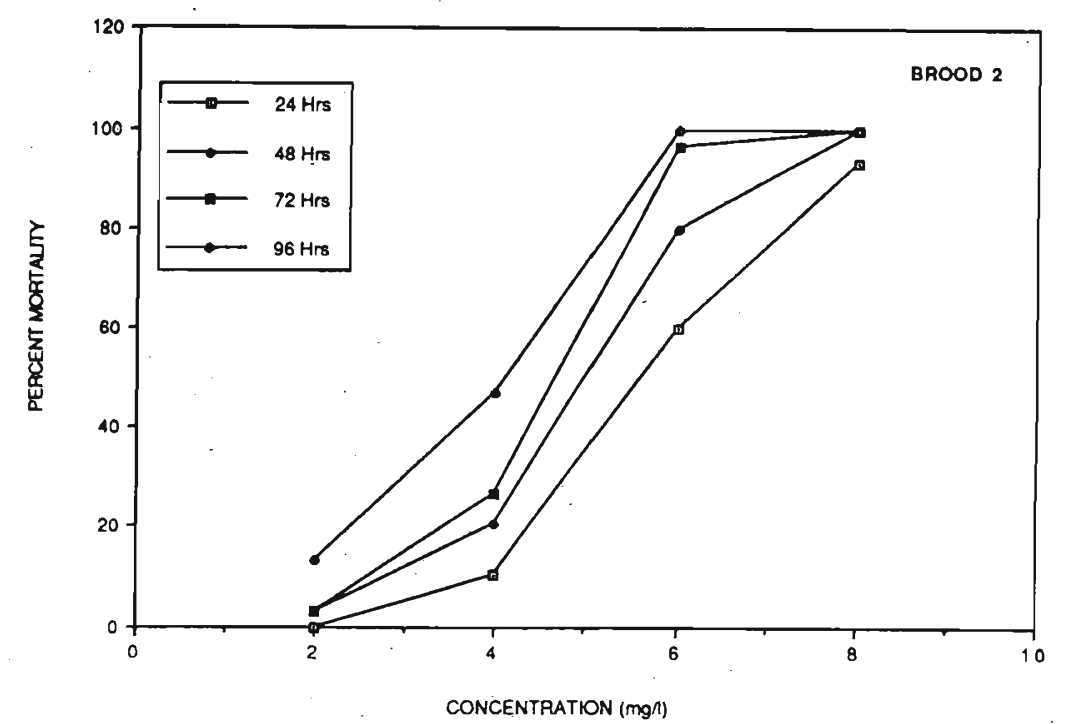

Figure 2: Per cent mortality of the juveniles of $M$. resenbergil (brood 2) exposed to different concentrations of hydrogen sulphide for $24,48,72$ and $96 \mathrm{~h}$. 
showed lower LCs0 values. Jones ${ }^{16}$ and Bonn and Follis ${ }^{17}$ showed that raising the $\mathrm{pH}$ could in turn lower the toxicity of un-ionized hydrogen sulphide. At higher $\mathrm{pH}$, the greater proportion of hydrogen sulphide is in the form of ionized hydrogen sulphide which is less toxic. It was also observed in the present study that at higher pH juveniles of brood 2 showed less toxicity effects.

Table 3. $\mathrm{LC}_{50}$ values and $95 \%$ confidence limits at indicated times during $96 \mathrm{~h}$ test of the toxicity of hydrogen sulphide.

\begin{tabular}{ccccc}
\hline Time & \multicolumn{2}{c}{ LC $_{50}$ values mg/ } & \multicolumn{2}{c}{$95 \%$ confidence limits mg/ } \\
\hline & brood 1 & brood 2 & brood 1 & brood 2 \\
\hline 24 & 6.36 & 5.57 & $5.81-6.95$ & $5.13-6.04$ \\
48 & 4.25 & 4.79 & $3.36-5.39$ & $3.77-6.09$ \\
72 & 3.03 & 4.25 & $2.65-3.46$ & $3.03-5.95$ \\
96 & 2.57 & 4.20 & $2.21-2.98$ & $2.38-7.39$ \\
\hline
\end{tabular}

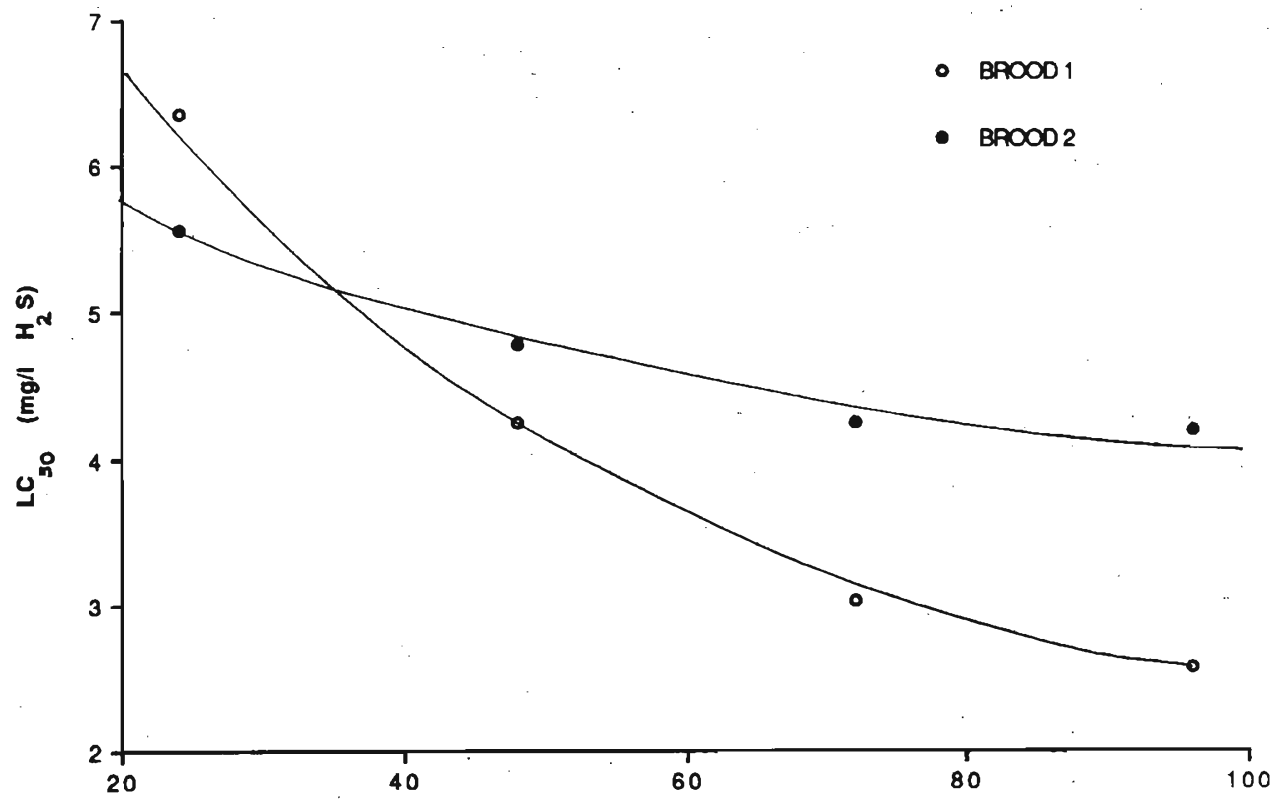

EXPOSURE TIME (hrs)

Figure 3: The loxicity curve of hydrogen sulphide for juveniles of $M$. rosenbergii. 
The toxicities of hydrogen sulphide to other aquatic organisms have been reported by various authors. Doudoroff and $\mathrm{Katz}^{18}$ reported that the concentrations below $10.0 \mathrm{mg} / \mathrm{l}$ (mostly $1.0-6.0 \mathrm{mg} / \mathrm{l}$ ) were lethal to several fish species such as Lepomis gibborus, Salmo gairdneri, Catostomus commersoni, Carassius auratus and Cyprinus carpio. ${ }^{18}$ Bonn and Follis reported that fish could survive in $\mathrm{H}_{2} \mathrm{~S}$ concentrations between 0.3 and $4.0 \mathrm{mg} / \mathrm{l}^{17}$ Colby and Smith showed that $0.3 \mathrm{mg} / 1$ sulphide were acutely lethal to the amphipod Gammanus pseudolimnaeus eggs and fry. ${ }^{1}$ Bonn and Follis found that $24 \mathrm{~h} \mathrm{LC}_{50}$ value for fingerlings of channel cat fish (Ictalurus punctatus) ranged from $0.53-0.8 \mathrm{mg} / \mathrm{l}$ of $\mathrm{H}_{2} \mathrm{~S}^{17}$ Peturiyawate reported that the $48 \mathrm{~h} \mathrm{LC}_{50}$ value for Clarius batrachus as $6.52 \mathrm{mg} / \mathrm{l}^{9}$ The $\mathrm{LC}_{50}$ values obtained in this study lie within the range given by Doudoroff and Katz. ${ }^{18}$ The value is lower than that observed for Clarius batrachus and Carassius auratus. ${ }^{9,10}$ Unfortunately, no data are available on the $\mathrm{H}_{2} \mathrm{~S}$ toxicity of other prawn species for comparison. The safe concentration of $\mathrm{H}_{2} \mathrm{~S}$ which is equivalent to $20 \%$ of the $\mathrm{LC}_{50}$ was calculated according to Peturiyawate ${ }^{9}$ and was found to lie within the range of $0.26-0.43 \mathrm{mg} / \mathrm{l}$ of hydrogen sulphide.

\section{Acknowledgements}

I thank the Food and Agricultural Organization/National Acoustical Contractors Association for funding this study under the young scientists programme in Bangkok, Thailand. I am grateful to Dr. Kwei Lin, who suggested this study, Dr. Mali Boonyaratpalin and Dr. Maitree Duangsawasdi for guiding and helping me during the conduct of experiments, to Mr. Arnnop Jirawithayaboon for his assistance, and to Miss. Chujit Thongprapai for typing the manuscript. My special thanks are due to Mrs. J. L. Antiporda for improving the manuscript.

\section{References}

1. Colby P.J. \& Smith L.L.Jr. (1967). Survival of walleye egg and fry on paper fiber sludge deposits in Rainy River, Minnesota, Transactions of the American Fisheries Society $96: 278-296$.

2. Van Horn W.M., Anderson J.B. \& Katz M. (1949). The effect of kraft pulp mill wastes on some aquatic organisms. Transactions of the American Fisheries Society 79 : 55-63.

3. Dorris T.C., Gould W. \& Jenkins C.R. (1960). Toxicity bio-assay of oil refinery effluents in Oklahoma, pp. 276-285. In: Biological problems in water pollution. Taft Sanitation Engineering Centre, U.S.A.

4. Ellis M.M. (1937). Detection and measurement of stream pollution. Bulletin of the Bureau of Fisheries 48: 365-437.

5. Boyd C.E. (1979). Water quality in warm water fish ponds. Auburn University Agricultural Experimental Station. (vii) p. 359. Auburn, Alabama. 
6. Adelman I.R. \& Smith L.L., Jr. (1970). Effect of hydrogen sulphide on northern pike eggs and sac fry. Transactions of the American Fisheries Society 99: 501-509.

7. Smith L.L. Jr. \& Oseid D. (1972). Effects of hydrogen sulphide to fish eggs and fry. Water Resources 6: 711-720.

8. Colman J.A. (1980). Unpublished data. National Inland Fisheries Institute, Bangkok, Thailand.

9. Peturiyawate O. (1982). Effects of hydrogen sulphide on cat fish (Clarius batrachus Linnaeus) and its antogonistic actions with some inorganic compounds. M.Sc. Thesis. Mahidol University, Bangkok.

10. APHA (American Public Health Association, American waste water Pollution Control Federation) (1975). Standard methods for the examination of water and waste water. (14th ed) New York.

11. Smith L.L. (1971). Influence of hydrogen sulphide on fish and arthropods. Preliminary completion report. Environment Protection Agency, U.S.A. Project. 18050 PCG. pp. 30.

12. Finney D.J. (1971). Probit Analysis. ( $3^{\text {rd }}$ ed) Cambridge University Press, London.

13. Litchfield J.T. \& Wilcoxon F. (1949). A simplified method of evaluating dose-effect experiments. Joumal Phammacology and Experimental Therapeutics 96: 99-113.

14. Kalyanamitr C. (1983). Effects of water temperatures on the acute toxicity of lead to giant freshwater prawn Macrobrachilum rosenbergii De Man. M. Sc. thesis. Mahidol University, Bangkok.

15. National Technical Information Service (1974). Hydrogen sulphide-health effects and recommendations. PB-233. pp. 15. Springfield VA, U.S.A.

16. Adelman I.R. \& Smith L.L.Jr. (1972). Toxicity of hydrogen sulphide to gold fish (Carassius auratus) as influenced by temperature, oxygen, and bioassay techniques. Joumal of the Fisheries Research Board, Canada 29: 1309-1317.

17. Jones J.R.E. (1948). A further study of the reaction of fish to toxic solutions. Journal of Experimental Biology 25: 22-34.

18. Bonn E.W. \& Follis B.J. (1967). Effects of hydrogen sulphide on channel catfish (Ictalunis punctatus). Transactions of the American Fisheries Society 96: 31-37.

19. Doudoroff P. \& Katz M. (1950). Critical review of literature on the toxicity of industrial wastes and their components to fish. (I) Alkalis, acids and inorganic gases. Sewage Industrial Wastes 22: 14332 -14580. 